The Journal of Agriculture and Environment Vol:17, Jun.2016

\title{
PROSPECTS OF BIOCHAR AS SOIL AMENDMENT IN NEPAL HILL FARMING SYSTEMS
}

Ngamindra Dahal ${ }^{1}$, Roshan Man Bajracharya ${ }^{1}$ and Juerg Merz ${ }^{2}$.

\begin{abstract}
Burning of biomass under controlled temperature and oxygen limited environment produces biochar along with syn-gases and bio-oil. A significant volume of literatures portray biochar as a remedial option to meet growing needs of amending agricultural soils for global food security and carbon sequestration to curb climate change. Biochar has generated huge interests among agro-practitioners mainly for its two sets of benefits. The first set of benefits is about desirable changes in soil function that includes enhanced soil microbial activity, retention of nutrients and moisture, alkaline effect for treating acidic soils and, increased porosity on soil structure. The second set includes enhanced adaptive capacity of agricultural systems to climate change impacts, and, carbon sequestration due to its recalcitrant nature that remain in soil for a very long period. These acclaimed effects of biochar on soils are among the much sought-after remedies to heal $a$ number of soil health ailments that millions of farmers and policy planners are looking for. However, effectiveness of biochar has yet to be examined carefully in different soil types over diverse topography corresponding with local cropping patterns. Matching properties of soils with those of biochar is a prerequisite for any interventions aimed at soil amendment. Properties of biochar generally depend on feedstock types, and temperatures during pyrolysis. This review analyses major published works on different aspects of biochar with the key question of whether promotion of biochar could be a viable solution to address some of the critical concerns of soil productivity in the Nepal mid hills and concludes with a note that there are serious knowledge gaps in two fronts - systematic practice of biochar production and application in agricultural farms is yet to take off, and, documented evidences of effectiveness of biochar on various soil types and cropping patterns are insignificant.
\end{abstract}

Key words: Application, biochar, climate change, farm yard manure, fertilizer,organic matter, sustainable soil management

\section{INTRODUCTION}

Traditionally, Nepali hill farmers practiced subsistence agriculture and relied mostly on farm yard manure (FYM) and some compost to replenish plant nutrients in soils. In recent decades, majority of farmers increasingly depend on industrial fertilizers with limited inputs of locally produced manure (Bajracharya \& Sherchan, 2009). Growing crop intensification is a prevalent practice among the hill farmers of Nepal from one or two crops per annual cropping cycle to intense farming of cash crops ( 3 to 4 crops/year). This has spurred on by increasing food and cash-crop demands along with the ready availability of agro-chemicals (Dahal \& Bajracharya, 2011). This has added pressure on lands where low organic matters and high acidity are evident that eventually lead to reduce productivity of lands (Bajracharya 2002). The main reasons for low yields are believed to be the lack of replenishment of soil organic matter and inadequate or inappropriate use of fertilizers (Sherchan \& Karki 2005). In hill agricultures, fertilizer retention capacity of lands, till the crop roots uptake it, is limited due to shallow layer of soil, low to high degree of slope and frequent runoffs after stormy rains. It's like a vicious cycle of low organic matter leading to increased susceptibility of soil erosion, thus, lower retention of fertilizers and less production of crops and further depletion of soil organic matter (SOM). Lal (2009) depicted two major causes for depleting soil organic matter (SOM). The first cause is the long-term use of extractive farming practices and, the second is the conversion of natural ecosystems such as forest land, prairie lands and steppes into croplands and grazing lands in Nepal where SOM stocks suffer losses due to a number of factors like less input of biomass, tillage practices, crop harvesting, excessive inputs of chemical fertilizers, and soil erosion.

\footnotetext{
${ }^{1}$ School of Science, Kathmandu University, Dhulikhel, Nepal

2 Helvetas Intercooperation, Kathmandu, Nepal Correspondence: ngamindra@gmail.com
} 
Hill farmers traditionally use farm-yard manure (FYM) as a significant source of organic matters based on local knowledge and techniques (Bajracharya and Sherchan, 2009). They prepare FYM out of locally available forest litters, crop residues as well as animal manures to replenish farmlands. With the advent of changing agricultural practices from low intensity (subsistence oriented) to more intensive cropping (commercial), farmers depend more on chemical fertilizers rather than FYM. Nevertheless, a significant number of hill farmers continue to use FYM particularly those who have adopted an improvised practice called 'sustainable soil management or SSM' as this helped them making FYM more effective and sustainable (Dahal \& Bajracharya, 2012). Given the diminishing trend of FYM inputs throughout the country, some urgent measures to tackle the issue are imperative. Locally produced biochar could be a potential answer to this solution.

\section{EVOLUTION OF BIOCHAR AS A SOIL AMENDMENT}

The history of reporting effects of biochar goes back to 1960s, when Sombroek (1966), for the first time, published a description of 'tera preta' from Amazon soil. Contemporary studies on biochar largely deal with testing of promises or limitations of its effects to amend field soils, developing device for pyrolyzing various types of biomass, and weighing options for biomass management. More recently, the growing climate change concerns have fueled interests on biochar as a promising tool to sequester carbon, enhance climate adoptability of agricultural soil and increase agronomic yield. This is spectacularly reflected in growing publications and rising portfolios of biochar in agricultural extension programs.

Traditionally, local farmers from various parts of world follow numerous techniques to prepare and use biochar based on their indigenous knowledge and practices. For example, in parts of Japan, China, India, Nepal and many other countries, farmers have long traditions of using pyrolysed biomass in their farmlands (Amonette \& Joseph, 2009). In Nepal, high mountain farmers have a tradition of producing on-farm biochar (Bajracharya et al, 2013), which they called 'bukma' in local language but their applications are limited to nursery beds of finger millet, potato and other vegetables. The modern biochar technologies are based on trials through cycles of research, development and field verifications undertaken by diverse groups of agencies and individuals. With the growing interests on biochar, there is a rapidly evolving knowledge on practices in various fronts of its production and application in response to diverse agricultural challenges such as climate change, rehabilitation of degraded farmlands, and, building more efficient and sustainable farming systems.

\section{BIOCHAR FUNCTIONS}

Properties of biochar determine the way how biochar functions within soil and its potential to act as a route to sequester atmospheric carbon dioxide (Downie et al. 2009). Nature of biochar-soil interactions largely depend on characteristics of biochar, which in turn, are determined by types of feedstock and pyrolyzing mechanisms (moderation of temperatures and oxygen). Biochar applications bring a change in soil structures, texture, porosity, particle size distribution and density, thereby potentially altering air oxygen content, water storage capacity and microbial and nutritional status of the soil within the plant rooting zone (Amonette and Joseph 2009). The suction effects of pores in biochar are attributed to create favorable environment for enhanced microbial activity due to holding of rich moistures and nutrients (Josheph et al, 2012). Biochar particles when applied in soils do not get decomposed like any other biomass, and exhibit enhanced sorption and cat-ion exchange capacities and alkaline properties that profoundly support healing a number of soil ailments such as acidity, nutrient leaching and poor rates of microbial activity.

The feedstock material, levels of oxygen supplied to the feedstock chamber and temperatures during pyrolysis determine the variability in physical and chemical properties of biochar (Lua et al 
2004; Gundale \& DeLuca 2006; Amonette \& Joseph 2009). Properties of biochar fluctuate depending on temperature and air control mechanisms while pyrolysing the biomass (feedstock). Biochar properties, mainly porosity and ash-content, are reportedly varied in slow and fast pyrolysis of feedstock with same composition. In general, slow pyrolysis (low temperature, often between 300 and 600 degree Celsius) biochar is preferred against fast pyrolysis (high temperature often above 600 degree Celsius) to avoid complete burning into ashes and increasing porosity of the charred particles. A variety of agricultural crop residues and by-products including coffee pulps and husk, invasive species of shrub or weeds, forest litters, organic wastes, chicken manures, sawdust, wastewood or a combination of these types of materials are commonly used as feedstock (Dahal \& Bajracharya, 2014, Brown et al., 2006; Abdullah \& Wu, 2009; Lucchini et al. 2014, Feng et al., 2012, Chun et al., 2004, Peng et al., 2011, Yao et al., 2011b). However, biochar practitioners often go for fast pyrolysis to meet their quantitative target of biochar volume.

O'Neill et al. (2009) report that biochar contributes to improve soil health by enhancing processes like soil nitrification, with the added benefits of catalyzing nitrous oxide reduction that lead to reduce GHG emissions and to some extent improving plant productivity. Biochar particles are nondecomposable hence, remains immobilized in soils for decades or longer. According to a review by Gurwick et al (2013), stability of biochar in soil depends on ecosystems, source and application methods among others and vary between 300 years to over 1000 years. The decomposition rate slows over time and stay longer. According to Angin and Sensoz, (2014), the processes of biochar formation from various types of biomass are complex and remain unexplained. The feedstock types and pyrolyzing process profoundly affect shaping of biochar characteristics. For example, biochar made out of animal manures tend to have higher $\mathrm{pH}$ than biochars pyrolysed from plant species (Novak et al. 2009; Singh et al. 2010; Spokas et al. 2011) although farmers rarely prefer such feedstock for various reasons. Animal manures are either applied directly in the field as major source of fertilizers or making compost or farmyard manure (FYM)

\section{BIOCHAR ATTRIBUTES}

The biochar literatures depict various scenarios of its effectiveness as a means of soil amendment. Majorities of studies based on field experimentations highlight positive effects but come with precautionary notes as they also mention of various limitations in terms of geographical coverage, duration, types of biochar and feedstock among others. Positive attributes of biochar include effectiveness for improving soil quality, increasing agricultural productivity, and addressing environmental and agronomic issues (e.g., climate change, soil degradation, low agronomic yield, eutrophication of surface and groundwater), and reducing GHG emissions through carbon sequestration. Recently, some studies (see Mukharjee \& Lal, 2013) have also emphasized on the need of critical review of results from biochar trials for building a more balanced explanation (without exaggerations) of its effects as a soil amendment. Comprehensive experiments on real field situations, not limited to the laboratory or greenhouse, are emphasized.

An overview on findings of biochar studies often raises ones expectations for the promising results of its incorporations in soils. The number of positive attributes exceeds the negative. The negative attributes are about uncertainties associated with beneficial effects that may require further testing for clarity. This also underlines the need of a systematic field research program that studies effectiveness of biochars representing a range of feedstock varieties and production methods, across climate and soil gradients. Lack of confidence of farmers and investors on promises of biochar adequately depicts the needs of boosting comprehensive plan of testing biochar in the areas where land degradation and productivity decline is more spectacular. This should also involve up-scaling across the diverse farming systems. 
The Journal of Agriculture and Environment Vol:17, Jun.2016

Figure 1: Positive and negative attributes of biochar applications (Source: A summary chart based on authors' review of biochar literatures listed in the references)

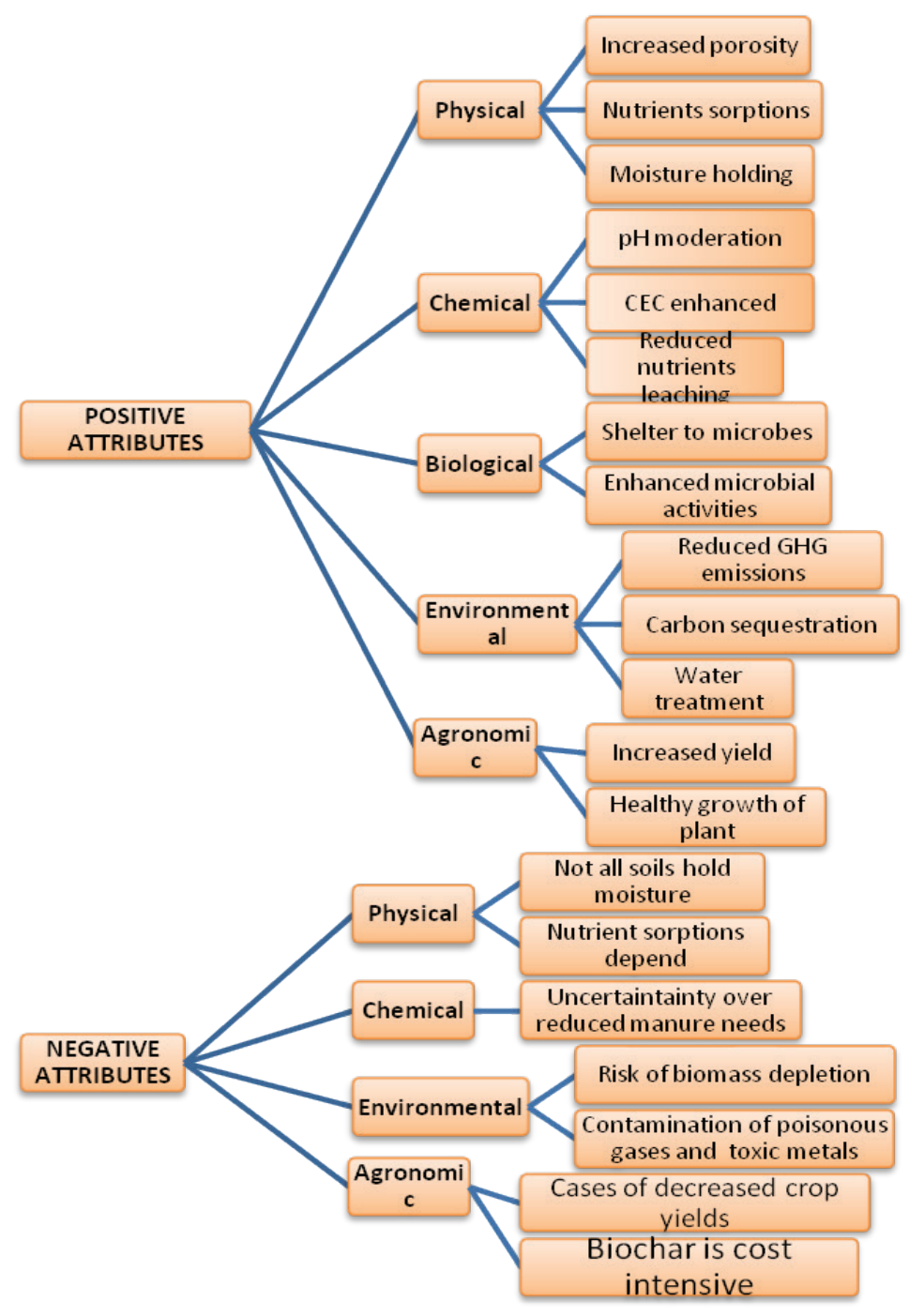

Manya (2012) reported that the immense variability among biochars and site-specific interactions with the soil and vegetation create a challenge in establishing clear relationships between physicochemical properties of soil and right composition of biochar. This implies to the need of refining current knowledge on relative influences of conversion technology and feedstock on biochar properties for greater efficiency on large-scale biochar production. Seasonal and spatial limitations of feedstock sources from agricultural fields and natural forests pose challenges for regular operation of biochar plants (Yuan et al. 2012). This also refers to the knowledge gap to be filled through innovations in pyrolysis mechanisms tied with field trials to ascertain the standard biochar productions with respect to the types of feedstock and conditions of soils.

According to Xie et al (2015) once biomass is pyrolyzed, labile organic matter (i.e., biomass) in the sample is effectively destroyed, while the mineralized (fixed) carbon remains intact, which 
highlight the fact that the temperatures applied in the pyrolysis process dictate the loss of labile $\mathrm{C}$ leaving behind the fixed organic $\mathrm{C}$ content in the resultant char. The authors further reported that concentrations of volatile matter and $\mathrm{C}$ content in biochar from agricultural residues are relatively lower than that from wood due to the limited content of lignocellulosic biomass in herbaceous species than in wood.

Acknowledging a range of published works on various aspects of biochar, Gurwick et al (2013) concluded on the need of a systematic field research program that investigates stability of biochars representing a range of feedstock and production methods, across climate and soil gradients. Therefore biochar is likely to bring a win-win strategy by building organic matters in soils, enhancing soil quality, improving agronomic productivity and thereby advancing food security marginalized and degraded lands.

\section{MIXED SCENARIOS OF BIOCHAR APPLICATION RESULTS}

Generally, studies acknowledge positive effects of biochar to enhance soil quality thereby increasing agricultural productivity, and mitigating environmental and agronomic problems (e.g. climate change, soil degradation, low agronomic yield, eutrophication of surface and groundwater) to reducing GHG emissions through carbon sequestration. They report that applications of biochar enhances soil chemical properties by (i) reduction in soil acidity and increase in availability of plant nutrients and cation exchange capacity (CEC) (Lehmann et al. 2003; Cheng et al. 2006; Liang et al. 2006; Lee et al. 2010); (ii) sorption of heavy metals (Freddo et al. 2012); (iii) immobilisation of toxic organic and inorganic compounds in soil (Beesley et al.2011; Ogbonnaya \& Semple 2013) and iv) liming effect of biochar in soil (Jeffery et al. 2011). Interactive effects of biochar on soils are commonly acknowledged in five aspects, namely, physical, chemical, biological, environmental and agronomic. Glaser et al. (2002) reported desirable effects of biochar on soil chemistry, Mukherjee and Lal (2013) on physical properties, (Lehmann et al. 2011) microbial communities and biota; and, Lehmann et al. (2006); Fowles (2007) on greenhouse gas (GHG) emissions. However, Gurwick (2013) cautions that optimistic claims about biochar's benefits to the soil environment contrast sharply with the limited amount of research on biochar's behavior and effects due to insufficient empirical evidence to support assertions of mitigating climate change significantly.

Biochar, an organic additive for soil amendment, improves soil health, thereby, increasing crop yields and productivity through reduced soil acidity, and minimizing the needs of some chemical and fertilizer inputs (Glaser et al 2002 and Lehmann and Rondon 2006). Lehmann et al (2003), and Steiner et al (undated) further informed of rich moisture after the use of biochar as a soil amendment probably due to sorption property of biochar that retains more water, nutrients and agrochemicals in soils for utilization of crop thus reducing leaching and run-off to ground and surface waters. Although, biochar particles resemble with charcoal, the process of preparing this differs from the formers; and, widely used as a useful ingredient with beneficial effect on soil fertility. Several studies (Inyang et al., 2010, Abdullah and Wu, 2009; Yu et al., 2009, Rondon et al., 2007) reported that as every feedstock material has different composition and proportions of cellulose, hemicelluloses and lignin with differential thermal degradation, quantity and characteristics of biochar vary depending on the contents of lignin and recalcitrant carbon. These findings are further analyised and summarized in table 2 to depict some prospects biochar applications at variety of agricultural soils and its corresponding remedial effects.

Table 2: Common problems with agricultural soils presented against corresponding remedial effects of biochar as reported in some studies 


\begin{tabular}{|c|c|c|c|}
\hline S.N. & $\begin{array}{l}\text { Common problems in } \\
\text { agricultural soils }\end{array}$ & $\begin{array}{l}\text { Favorable effects of biochar } \\
\text { applications }\end{array}$ & References \\
\hline 1 & $\begin{array}{l}\text { Growing acidity in } \\
\text { agricultural lands limiting } \\
\text { growth of microorganisms }\end{array}$ & $\begin{array}{l}\text { In most cases biochar exhibits } \\
\text { liming effects, thus, contributes to } \\
\text { neutralize soil acidity thus helping } \\
\text { enhanced microbial activity in soil. }\end{array}$ & $\begin{array}{l}\text { Jeffery et al. 2011, Glaser } \\
\text { et al } 2002 \text { Lehmann et al. } \\
\text { 2011; Cheng et al. 2006; } \\
\text { Liang et al. 2006; Lee et } \\
\text { al. } 2010\end{array}$ \\
\hline 2 & $\begin{array}{l}\text { Losses of nutrients from } \\
\text { slopes and terraced farms } \\
\text { in hilly regions }\end{array}$ & $\begin{array}{l}\text { Biochar amended soils show higher } \\
\text { rate of sorption capacity leading to } \\
\text { reduced nutrient losses }\end{array}$ & Glaser et al 2002 \\
\hline 3 & $\begin{array}{l}\text { Low moisture holding } \\
\text { capacity (shallow soil) }\end{array}$ & Longer/higher moisture holding & et al (2003) \\
\hline 4 & $\begin{array}{l}\text { Low uptake of nutrients by } \\
\text { plants/poor microbial } \\
\text { functions }\end{array}$ & $\begin{array}{l}\text { Higher CEC is an inherent } \\
\text { characteristic of biochar that } \\
\text { boosts microbial functions and } \\
\text { increased nutrient uptake by } \\
\text { plants. }\end{array}$ & $\begin{array}{l}\text { Glaser et } \text { al } 2002 \\
\text { Lehmann et al. 2003; } \\
\text { Cheng et al. 2006; Liang } \\
\text { et al. 2006; Lee et al. } \\
2010\end{array}$ \\
\hline 5 & $\begin{array}{l}\text { Depleting } \\
\text { matters/ low SOM and } \\
\text { spread out of toxic } \\
\text { compounds }\end{array}$ & $\begin{array}{l}\text { Biochar remains locked in soils, } \\
\text { holds nutrients leading to } \\
\text { increased organic matter and } \\
\text { immobilize toxic compounds }\end{array}$ & $\begin{array}{l}\text { Lehmann and Rondon } \\
\text { 2006, Beesley et al.2011; } \\
\text { Ogbonnaya and Semple } \\
2013\end{array}$ \\
\hline 6 & $\begin{array}{l}\text { Unmet demands of } \\
\text { fertilizers and other inputs } \\
\text { to the soil }\end{array}$ & $\begin{array}{l}\text { Reduced needs of fertilizers and } \\
\text { other agro-inputs in biochar } \\
\text { amended soil }\end{array}$ & $\begin{array}{l}\text { Lehmann and Rondon } \\
\text { 2006, Glaser et al } 2002\end{array}$ \\
\hline 7 & $\begin{array}{l}\text { GHG emissions } \\
\text { agricultural activities }\end{array}$ & $\begin{array}{l}\text { Reduced GHG emissions to net } \\
\text { sequestration as biochar is locked } \\
\text { into soils (stability of biochar) }\end{array}$ & $\begin{array}{l}\text { Gurwick et al, 2013, } \\
\text { Lehmann et al. (2006); } \\
\text { Fowles (2007), Jeffery et } \\
\text { al. } 2011\end{array}$ \\
\hline 8 & Low crop productivity & $\begin{array}{l}\text { Increased productivity of crops } \\
\text { such as on pumpkin that reportedly } \\
\text { increased up to four-fold. }\end{array}$ & $\begin{array}{l}\text { Lehmann and Rondon } \\
\text { 2006, Glaser et al 2002, } \\
\text { Schmidt et al, 2015. }\end{array}$ \\
\hline
\end{tabular}

NEW INITIATIVES AND ISSUES FOR MAINSTREAMING BIOCHAR APPLICATIONS IN NEPAL

Biochar continues to gain global attention as a potential cure for a range of problems associated with soil productivity and crop yields even though uncertainties remain with its effectiveness on soil amendment (Kim et al. 2012). Whether biochar would serve as a meaningful remedy to improve agricultural soils in mid hills still remains as a research question due to lack of sufficient trials and validation in the diverse eco-agricultural contexts of the regions. For sustained productivity against a range of natural (e.g. soil erosion, climate change) and anthropogenic factors (e.g. inadequate organic inputs to maintain fertility) have been attributed to the diminishing productivity of the mountain agricultural soils requiring remedial research and policy actions to address the issue. Dahal (1997) reported that core issues of reforming the agriculture sector remained largely unchanged since 1950s when needs of crop intensification, expanding irrigation facilities, and, switching to mechanized agriculture, as well as, industrial fertilizers were emphasized to address the low productivity and declining soil fertility. More recently, Sunam, et al (2015) pointed out labor migration as a contributing factor to accelerate impoverishment of soils due to increased costs of agricultural inputs and labor.

Against this background, Bishwakarma et al (2014) reported a success story from mid hill region where over 100,000 farmers reaped benefits of increased productivity after 10 years of interventions under sustainable soil management (SSM) practices. This approach has been effective to enhance soil organic matters in the lands that reflect on the improved physical, chemical and 
biological characteristics of soil. Retaining soil nutrients and moistures, however, remains a critical challenge in cultivated lands with relatively shallow soil layer and high degree of slopes. Here, the biochar, which is yet to be tested and adopted as a viable tool, can play a role due to its sorption property that helps retain nutrients and moistures to make available for plants. Beyond the scope of traditional practices, major initiatives towards mainstreaming biochar applications are discussed here.

Piloting activities of biochar production and application have recently been launched in Nepal. For example, Nepal Agriculture Council (NARC) is experimenting with biochar in its research pocket zones for possible use to enhance soil productivity in degraded lands. A collaboration of Nordik Development Fund (NDF), Asian Development Bank (ADB) and NARC is piloting biochar in three agroecological zones of Nepal, namely, mountain, mid hills and plain. Quality of biochar and its effective applications are the key priorities (NDF, 2013) ${ }^{1}$. Some non-governmental agencies, namely, Helvetas Intercooperation and Nepal Agroforestry Foundation (NAF) are also undertaking field trials (Table 3). These actions are directed towards generating more evidences on effectiveness of biochar in various soils types and vegetation conditions. However, the question remains whether the trials performed in limited conditions produce sufficient evidences to making policy decisions in favor of spending the public funds provisioned for supporting agriculture development.

Table 3: Agencies undertaking biochar programs in Nepal

\begin{tabular}{|l|l|l|}
\hline Agency of & $\begin{array}{l}\text { Types } \\
\text { activity } \\
\text { interventions }\end{array}$ \\
\hline $\begin{array}{l}\text { ADB in collaboration } \\
\text { with Nepal Agriculture } \\
\text { Research Council and } \\
\begin{array}{l}\text { Nepal Academy of } \\
\text { Sciences and Technology }\end{array}\end{array}$ & $\begin{array}{l}\text { Action } \\
\text { research, } \\
\text { piloting }\end{array}$ & $\begin{array}{l}\text { Nordic Development Fund, 3 eco-regions - high } \\
\text { mountains, mid hills and Tarai, 2014 -16, production } \\
\text { tests, trials on soil amendment, carbon sequestration, } \\
\text { and energy saving stoves. }\end{array}$ \\
\hline $\begin{array}{l}\text { Department Environment Science } \\
\text { and Engineering, } \\
\text { Kathmandu University }\end{array}$ & Action research & $\begin{array}{l}\text { Helvetas Intercooperation, Sindhupalchok, Kavre and } \\
\text { Lalitpur of Nepal, 2013-15, }\end{array}$ \\
\hline $\begin{array}{l}\text { Multi-stakeholders } \\
\text { Forestry Programme }\end{array}$ & $\begin{array}{l}\text { Community } \\
\text { support }\end{array}$ & $\begin{array}{l}\text { Jointly funded by Swiss, UK and Finland, 2013-14, } \\
\text { support to communities of small holding farmers for } \\
\text { livelihood improvements }\end{array}$ \\
\hline $\begin{array}{l}\text { Nepal Agroforestry } \\
\text { Foundation Scientific } \\
\text { research }\end{array}$ & $\begin{array}{l}\text { Norwegian Geotechnical Institute and the Norwegian } \\
\text { University of Life Sciences, 2012 onwards. Nepal is } \\
\text { one of the 4 countries where the project has been } \\
\text { launched. }\end{array}$ \\
\hline $\begin{array}{l}\text { Local Initiative for } \\
\text { Biodiversity Research } \\
\text { and Development }\end{array}$ & $\begin{array}{l}\text { Action } \\
\text { research, } \\
\text { piloting }\end{array}$ & $\begin{array}{l}\text { DanChurchAid, 2014-2016, support for livelihood } \\
\text { improvement among low income households }\end{array}$ \\
\hline
\end{tabular}

Limited tested knowledge of biochar applications in the Himalayas: We found hardly any peer reviewed journal articles that are based on comprehensive experimentations of biochar in Nepali soils. Nepali farmers traditionally practice open-burning of agricultural wastes prior to the cropping season with a belief that ashes of biomass help enriching soils. Majority of studies are based on experiments in the soils of temperate climates, namely, Asia, Europe, Australia, US and South America. Among Asian countries, biochar researches are picking up in recent years in China,

${ }^{1}$ http://www.ndf.fi/project/pilot-project-test-climate-change-benefits-biochar-ndf-c55 as access on Jul 30, 2015 
Indonesia, and Japan. Nepali researchers have also published some papers on biochar but they are not based on Nepali soils and climates.

Uncertainties persist on results of biochar experimentations: Uncertainty persists on the expected benefits of biochar despite of the growing volumes of research findings in favor of its positive impacts. Some critical views on biochar highlight two major gaps: first, the present research findings are coming from the limited field experiments that cannot represent the world's vast and diverse conditions of soils and climates. Second, the results are not consistent, leaving a number of questions unanswered. According to Mukherjee and Lal (2014), biochar advocacy is growing worldwide without adequate scientific knowledge on basic soil processes and cost-benefit analysis of biochar application to soil. Likewise, Gurwick et al (2013) emphasize on more research needs on biochar despite its beneficial effects on soil environment particularly to assess its effectiveness in different soil profiles, climatic conditions and crop varieties. This is true in Nepal where biochar has not been tested beyond exception. This leaves a huge knowledge gap and opportunity for fresh researches and field experimentations in the region. Scores of prominent reviews of biochar studies (for example Mukherjee \& Lal, 2014, ) indicate the needs of comprehensive field testing before moving on policy reform in favour of using biochar, which has significant cost implications.

Maintaining production quality of biochar: The actors determining quality of biochar are feedstock types, temperature and oxygen level. Majority of studies indicate that biochar produced in low temperature, preferably below 500 degree Celsius, is more effective (Dahal and Bajracharya, 2014). Information regarding availability of minerals in biochar is particularly relevant to raise confidence on potential biochar benefits to plant growth (e.g. see Gundale \& DeLuca 2007). In developing societies, biochar is produced mostly from locally designed and assembled retorts or stoves. These stoves are run manually, for filling with feedstock, firing and adjusting temperatures. Thus, the quality of biochar often varies from one batch to other that highlights the need of testing properties of each lot before field applications. This becomes a critical issue particularly for studying effects of biochar when one needs to know its physical and chemical properties including the microscopic structures. This involves significant costs and time, thus, has been a major constraint for ascertaining the effects of biochar on soil properties and plant growth. Types of feedstock and burning rates shape the properties of biochar in terms of its taste, odor, color and other chemical and physical characteristics.

Sources of feedstock: Availability of sufficient volumes of renewable feedstock sources is critical for promoting biochar. Usually the preferred feedstock type is the underutilized biomass available at the farm fields sites, households, market places or agro-processing mills. Feedstock varies depending on preferences of farmers, availability and accessibility of biomasses, season (rainy season not a preferred time) and biochar-making devices. For example, majority of hill farmers prefer locally available forest litters and invasive species of grass and shrubs, while in suburban areas the preferences shift to bio-wastages such as rice husks, coffee pulps and wooden dust from mills. Others include wastes from vegetables, fruits and crops. Some prefer mix others prefer single type feedstock. Nevertheless, varieties of feedstock are available in limited volumes depending on seasons and ecological conditions. For example, Dahal and Bajracharya (2013) found forest litter and weeds, coarse rice husks, coffee pulps and sawdust as possible sources of feedstock in parts of mid hill Nepal, which are available in specific seasons and limited quantity as a source of biochar feedstock.

Types of stoves for making biochar: A perception survey by these authors among 100 farmers who attended training programs on 'how to make and apply biochar' in seven hill districts of Nepal between Jan and June 2015, revealed that majority of them are interested to adopt biochar making and applications as an integral part of their improved agricultural practices. Majority of them pointed out that accessing an appropriate design of retort or stove for making 
biochar is the top constraint. The existing designs are not so appropriate for their dual needs of making biochar and daily cooking or preparing cattle feed. They also found the stoves expensive and time-taking as they spend nearly 4 hours for producing about 3 kilograms of biochar in a session. They also emphasized on a robust design so that the stoves need no maintenance at least for a year.

In summary, the aforementioned discussions depict a scenario that biochar is increasingly getting attentions of farmers and researchers alike to restore soil fertility. Its properties of nutrient sorption against leaching, alkalinity for neutralizing acidic soils, retention of moistures, enhanced microbial activities near the cavities of biochar particles and reduced compactness of soil structures are the key properties. It is also emphasized that biochar should be taken as a catalizer, not a fertilizer, and, can show its effects more clearly in degraded soils with low moisture holding capacity where it helps enhancing retention of nutrients and moistures. In this ground, biochar offers an alternative technique for enhancing not only productivity of agricultural lands but also for carbon sequestration through added organic matter in the soil which is locked for centuries. These benefits, however, come with costs and uncertainties.

\section{CONCLUSIONS AND FUTURE PROSPECTS}

Although biochar offers a promising opportunity to reduce climate change impacts and enhance adaptability of agricultural sector, a significant knowledge gap exists about its costs and benefits. Fertility losses are linked to several factors including depletion of soil organic matters as a result of lower agricultural inputs, leaching of nutrients, crop intensification and excessive use of chemical fertilizers (Dahal \& Bajracharya, 2012), for which biochar offers a viable alternative to minimize these effects.

Although studies generally agree on beneficial effects of biochar to enhance soil productivity, they also call for taking precautions to carefully match biochar properties with those of soils with active participations of local farmers. Of the reviewed literatures on biochar, we broadly identified three types of findings. The first type demonstrates significant effects of biochar that is capable enough to treat several soil health problems with little or no negative effects, the second type presents mix or inconclusive results, and the third types present insignificant or no beneficial effects, and offer critical view on promoting biochar. Nevertheless, the limited studies conducted in Nepal's diverse soil and climate conditions, clearly indicate very positive effects of biochar in improving soil qualities and crop productivity. Thus, Nepal's agriculture sector offers a huge potential for reducing emissions from soil and enhancing sustainable productivity of the land through biochar enrichment. In this context, there is a potential of reducing organic soil carbon losses that can be produced into carbon emission reduction credits and traded like any other farm produce.

\section{REFERNCES}

Abdullah, H., and Wu, H. W. 2009. Biochar as a fuel: Properties and grindability of biochars produced from the pyrolysis of mallee wood under slow-heating conditions. Energy Fuels. Vol 23, pp 4174-4181.

Amonette, J., Joseph, S. 2009. Characteristics of biochar micro-chemical properties. In: Biochar for Environmental Management: Science and Technology ( Eds. Lehmann, J., \& Joseph, S.). Earthscan, London, pp. 13-32. 
Angin, D., and Sensoz, S. 2014. Effect of pyrolysis temperature on chemical and surface properties of biochar of rapeseed (Brassica napus L.). International Journal of Phytoremediation. Vol.16, Issue 7-8, pages 684-693. (DOI: 10.1080/15226514.2013.856842)

Bajracharya, R.M. (2002). Fertility and productivity parameters for soil from five mid-hill districts of central Nepal. In: Proceedings of international seminar on mountains. Kathmandu. Pp 141-150. Royal Nepal Academy of Science and Technology.

Bajracharya, RM and Sherchan, D. P.2009. Fertility status and dynamics of soils in the Nepal Himalaya: A review and analysis. In: Soil Fertility, (Eds. D.P. Lucero and J.E. Boggs). Nova Science Publishers, Inc. Pp. 111-135.

Beesley, L., Moreno-Jim' enez, E., Gomez-Eyles, J. L., Harris, E., Robinson, B., and Sizmur, T. 2011. A review of biochars' potential role in the remediation, re-vegetation and restoration of contaminated soils. Environmental Pollution, 159, pp. 3269-3282.

Bishwakarma, B. K., Dahal, N. R., Allen, R., Rajbhandari, N. P., Dhital, B. K., Gurung, D. B., and Baillie, I. C. 2014. Effects of improved management and quality of farmyard manure on soil organic carbon contents in small-holder farming systems of the middle hills of Nepal. Climate and Development, 111. http://doi.org/10.1080/17565529.2014.966045

Brown, R. A., Kercher, A. K., Nguyen, T. H., Nagle, D. C., and Ball, W. P. 2006. Production and characterization of synthetic wood chars for use as surrogates for natural sorbents. Organic Geochemistry 37, 321-333.

Chatterjee, S., Santos, F., Abiven, S., Itin, B., Stark, R.E., Bird, J.A., 2012. Elucidating the chemical structure of pyrogenic organic matter by combining magnetic resonance, mid-infrared spectroscopy andmass spectrometry. Org. Geochem. 51, 35-44.

Cheng, C.H., Lehmann J., Engelhard, M.H. 2008. Natural oxidation of black carbon in soils: Changes in molecular form and surface charge along a climosequence. Geochimica et Cosmochimica Acta 72, 1598-1610. (doi:10.1016/j.gca.2008.01.010)

Cheng C.H., Lehmann J., Thies J.E., Burton S.D., and Engelhard, M.H. 2006. Oxidation of black carbon by biotic and abiotic processes. Organic Geochemistry, 37, 1477-1488. (doi:10.1016/j.orggeochem.2006.06.022)

Chun, Y., Sheng, G.Y., Chiou, C.T., Xing, B.S. 2004. Compositions and sorptive properties of crop residue derived chars. Environmental Science and Technology, 38(17), 4649-4655. (doi:10.1021/es035034w)

Dahal, N., 1997. Review of the Proceedings of the First Agriculture Conference in Nepal. Water Nepal - Journal of Water Resources Development, Vol. 5 (2). Page 149-164.

Dahal, N., Bajracharya, R.M., and Merz, J., 2014: Soil Properties and Carbon Stock Quantification in Coffee Agro-forestry of Mid-Hills Nepal. In: Proceedings of International Conference on Forests, Soil and Rural Livelihoods in a Changing Climate (27-30 September). Kathmandu University.

Dahal, N., \& Bajracharya, R.M. 2011. Prospects of soil organic carbon sequestration; Implications for Nepal's mountain agriculture. Journal of Forest and Livelihood, 9,1-14.

Dahal, N.,\& Bajracharya, R.M. 2012. Effects of sustainable soil management practices on distribution of soil organic carbon in upland soils of Mid-hills of Nepal. Nepal Journal of Science and Technology, 13, 133-141.

Dahal, N.R. 2012. Prospects of enhancing soil organic carbon in sloping farm terraces of Mid Hills Nepal through sustain- able soil management practices (Thesis for M.Phil Degree). Department of Environmental Science and Engineering, Kathmandu University, Dhulikhel.

Downie, A., Crosky, A., and Munroe, P., 2009. Physical properties of biochar. In: Biochar for Environmental Management: Science and Technology (Lehmann, J., Joseph, S. (Eds.). Earthscan, London, pp. 1332.

Feng, Y. Z., Xu, Y. P., Yu, Y. C., Xie, Z. B., and Lin, X. G. 2012. Mechanisms of biochar decreasing methane emission from Chinese paddy soils. Soil Biology and Biochemistry, 46, 80-88.

Fowles, M. 2007. Black carbon sequestration as an alternative to bioenergy. Biomass and Bioenergy 31:426432.

Freddo A., Cai C., and Reid B.J. 2012 Environmental contextualisation of potential toxic elements and polycyclic aromatic hydrocarbons in biochar. Environmental Pollution, 171,18-24. (doi:10.1016/j.envpol. 2012.07.009) 
The Journal of Agriculture and Environment Vol:17, Jun.2016

Glaser, B., J. Lehmann, C. Steiner, T. Nehls, M. Yousaf, and W. Zech. 2002. Potential of pyrolysed organic matter in soil amelioration. Paper presented in the 12th ISCO conference, Beijing, China, 26-31 May.

GON, 2011. Economic survey: Fiscal year 2010/2011, Ministry of Finance, Government of Nepal, Kathmandu.

Gundale, M.J., and DeLuca, T.H. 2006. Temperature and substrate influence the chemical properties of charcoal in the ponderosa pine/Douglas-fir ecosystem. Forest Ecology and Management , 231, 8693.

Gundale, M., and DeLuca, T. 2007. Charcoal effects on soil solution chemistry and growth of Koeleria macrantha in the ponderosa pine/Douglas-fir ecosystem. Biol. Fertil. Soils, 43:303-311. (doi:10.1007/s00374-006-0106-5)

Gurwick, N.P., Moore, L.A, Kelly C. and Elias, P. 2013. A systematic review of biochar research with a focus on its stability in situ and its promise as a climate mitigation strategy. PLOS ONE, 8(9): 75932. (doi:10.1371/journal.pone.0075932)

Haefele S, Konboon Y, Wongboon W, Amarante S, Maarifat A, Pfeiffer E, and Knoblauch C. 2011. Effects and fate of biochar from rice residues in rice-based systems. Field Crops Res. 121:430-441.

Hammes, K., Torn, M. S., Lapenas, A. G. and Schmidt, M. W. I. 2008. Centennial black carbon turnover observed in a Russian steppe soil, Biogeosciences Discussion, vol 5, pp661-683.

Hammes K, Schmidt M. 2009. Changes in biochar in soil. In: Biochar for environmental management: science and technology (Lehmann J\& Joseph S, eds.). London: Earthscan; p. 169-182.

Inyang, M., Gao, B., Pullammanappallil, P., Ding, W., and Zimmerman A.R. 2010. Biochar from anaerobically digested sugarcane bagasse. Bioresour. Technol. 101(22):8868-8872.

Jeffery, S., Verheijen, F.G.A., van der Velde, M, Bastos, A.C. 2011: A quantitative review of the effects of biochar application to soils on crop productivity using meta-analysis. Agric. Ecosyst. Environ., 144(1), 175-187. (doi:10.1016/j.agee.2011.08.015)

Kim, K. H., Kim, J., Cho, T., and Choi, J.W. (2012). Influence of pyrolysis temperature on physicochemical properties of biochar obtained from the fast pyrolysis of pitch pine (pinus rigida). Bioresour. Technol., 118, 158-162.

Knoblauch, C., Maarifat, A.A., Pfeiffer, E.M., Haefele, S.M. 2011. Degradability of black carbon and its impact on trace gas fluxes and carbon turnover in paddy soils. Soil Biology and Biochemistry. published online.

Lal, R. (2009). The Potential for Soil Carbon Sequestration. In Agriculture and climate change:An Agenda for negotiation in Copenhagen for Food, Agriculture and the Environment. IFPRI Policy Brief 5, pp 16 22.

Lee, J. W., Hawkins, B., Day, D. M., and Reicosky, D. C. 2010. Sustainability: The capacity of smokeless pyrolysis for energy production, global carbon capture and sequestration. Energy and Environmental Science 3, 1695-1705.

Lehmann, J., Rondon. M. 2006. Biochar soil management on highly weathered soils in the humid tropics. In: Biological approaches to sustainable soil systems (Uphoff, N. editor). Boca Raton (FL): CRC Press; p. 105-124.

Lehmann, J., J. P. da Silva Jr., C. Steiner, T. Nehls,W. Zech, and B. Glasser. 2003. Nutrient availability and leaching in an archaeological Anthrosol and a Ferralsol of the central Amazon Basin: Fertilizer, manure and charcoal amendments. Plant and Soil, 249:343-357.

Lehmann J, Gaunt J, Rondon M. 2006. Biochar sequestration in terrestrial ecosystems - a review. Mitigation Adaptation Strategy Global Change. 11:395-419.

Lehmann, J., Rillig, M.C., Thies, J., Masiello, C.A., Hockaday, W.C., and Crowley, D. 2011. Biochar effects on soil biota - a review. Soil Biol Biochem. 43:1812-1836.

Liang, B., Lehmann, J., Kinyangi, D., Grossman, J., O’Neill, B., Skjemstad, J.O., Thies, J., Luizao, F.J., Peterson, J., \& Neves, E.G. 2006. Black carbon increases cation exchange capacity in soils. Soil Sci. Soc. Am. J., 70, 1719-1730.

Lua, A. C., Yang, T., and Guo, J. 2004. Effects of pyrolysis conditions on the properties of activated carbons prepared from pistachio-nut shells. Journal of Analytical and Applied Pyrolysis, 72, 279-287.

Lucchini, P., Quilliam, R. S., DeLuca, T. H., Vamerali, T., and Jones, D. L. 2014. Increased bioavailability of metals in two contrasting agricultural soils treated with waste wood-derived biochar and ash. Environ. Sci. Pollut. Res. Int., 21, 3230-3240. 
Major, J., Lehmann, J., Rondon, M., Goodale, C., 2010. Fate of soil-applied black carbon: downward migration, leaching and soil respiration. Global Change Biology, 16, 1366-1379.

Manya, J.J. 2012. Pyrolysis for biochar purposes: A review to establish current knowledge gaps and research needs. Environ. Sci. Technol., 46 (15), pp 7939-7954. (DOI: 10.1021/es301029g)

Mukherjee, A., and Lal, R. 2013. Biochar impacts on soil physical properties and greenhouse gas emissions. Agron. 3:313-339.

Mukharjee, A. and Lal, R. 2014. Biochar dilemma. Soil Research, Issue 52, pp 217-230. (http://dx.doi.org/10.1071/SR13359)

Novak, J.M., Lima, I. , Xing, B. , Gaskin, J.W. , Steiner, C. , Das, K.C. , Ahmed, M. , Rehrah, D. , Watts, D.W., Busscher, W.J. and Schomberg, H. 2009. Characterization of designer biochar produced at different temperatures and their effects on a loamy sand. Ann. Environ. Sci. 3:195-206.

Ogbonnaya, U., and Semple, K. 2013. Impact of biochar on organic contaminants in soil: A tool for mitigating risk? Agronomy, 3, 349-375. (doi:10.3390/agronomy3020349).

Peng, X., Ye, L.L., Wang, C.H., Zhou, H., and Sun, B. 2011. Temperature- and duration-dependent rice strawderived biochar: Characteristics and its effects on soil properties of an Ultisol in southern China. Soil \& Tillage Research, 112, 159-166. (doi:10.1016/j.still.2011.01.002)

Rondon, M. A., Lehmann, J., Ram' irez, J., and Hurtado, M. 2007. Biological nitrogen fixation by common beans (Phaseolus vulgaris L.) increases with biochar additions. Biology and Fertility of Soils, 43, 699-708.

Schmidt, H.P., Pandit, B.H. , Martinsen, V., Cornelissen, G, Conte, P. and Kammann,C.I., 2015. Fourfold increase in pumpkin yield in response to low-dosage root zone application of urine-enhanced biochar to a fertile tropical soil. Agriculture, 5(3), 723-741; doi:10.3390/agriculture5030723

Sherchan, D.P. \& Karki, K.B. 2005. Plant nutrient management for improving crop productivity in Nepal. In: Proceedings of regional workshop on improving plant nutrient management for better farmer livelihood, food security and environmental sustainability, pp 41-57. December 12-16. Beijing, China.

Singh, B., Singh. B.P., Cowie, A.L. 2010. Characterisation and evaluation of biochars for their application as a soil amendment. Australian Journal of Soil Research, 48, 516-525. (doi:10.1071/SR10058)

Sombroek, W.G. 1966. Amazon soils-a reconnaissance of soils of the Brazilian Amazon region. Centre for Agricultural Publications and Documentation: Wageningen, The Netherlands.

Spokas, K.A., Novak, J.M., Stewart, C.E., Cantrell, K.B., Uchimiya, M., DuSaire, and M.G., Ro, K.S. 2011. Qualitative analysis of volatile organic compounds on biochar. Chemosphere, 85, 869-882. (doi:10.1016/j.chemosphere. 2011.06.108)

Steiner, C., Teixeira. W.G., Lehmann, J., Nehls, T., deMacedo. J.L.V., Blum, W.E.H., Zech, W. 2007. Long term effects of manure, charcoal and mineral fertilization on crop production and fertility on a highly weathered Central Amazonian upland soil. Plant and Soil, 291, 275-290. (doi: 10.1007/s11104-007-9193-9)

Sunam, R.K., and McCarthy, J.F. (2015): Reconsidering the links between poverty, international labour migration, and agrarian change: critical insights from Nepal. The Journal of Peasant Studies. (DOI: 10.1080/03066150.2015.1041520)

Xie, T., Reddy, K.R., Wanga, C., Yargicoglub, E. \& Spokas, K. 2014. Characteristics and applications of biochar for environmental remediation: A review. Critical reviews in environmental science and technology. DOI- 10.1080/10643389.2014.92

Yao, Y., Gao, B., Inyang, M., Zimmerman, A. R., Cao, X. D., Pullammanappallil, P., and Yang, L. Y. 2011. Biochar derived from anaerobically digested sugar beet tailings: characterization and phosphate removal potential. Bioresour. Technol., 102, 6273-6278.

Yu, X. Y., Ying, G. G., and Kookana, R. S. 2009. Reduced plant uptake of pesticides with biochar additions to soil. Chemosphere, 76, 665-671.

Yuan, S., Dai, Z. H., Zhou, Z. J., Chen, X. L., Yu, G. S., and Wang, F. C. 2012. Rapid co-pyrolysis of rice straw and a bituminous coal in a high-frequency furnace and gasification of the residual char. Bioresour. Technol., 109, 188-197. 